\title{
Research of China's Hulusi, Bau Society
}

\author{
Hongfei Liu
}

College of Music, Hubei Engineering University, Xiaogan Hubei, 432000, China

\section{Keywords: Hulusi, Bau, Society}

\begin{abstract}
This article from the perspective of social and cultural backgrounds, takes China Hulusi, Bau Society as a research subject to study Hulusi, Bau music booming in recent years, this phenomenon is to expect to Hulusi, Bau musical development law more understanding.
\end{abstract}

\section{Introduction}

Hulusi, Bau Society is a nongovernmental organization by the Hulusi, Bau music societies. In recent years, with the rapid development of Hulusi, Bau music, Hulusi, Bau Institute is also developing rapidly, some provinces, cities, districts have been established Hulusi, Bau learn effectively promote and facilitate the Hulusi, Bau music development of. In the field of music Hulusi study, not yet have to Hulusi, Bau Institute research appears as the object of study, this paper this perspective, research in the social and cultural context that Hulusi, Bau music in recent years of prosperity the development of this phenomenon in order to expect to Hulusi, Bau musical development of greater awareness of the law.

\section{Development status of China's Hulusi, Bau society}

Societies(some are named specialized committee)of Hulusi, Bau established in recent years as follows:

Table 1. Establishment status of Hulusi, Bau societies in various regions in China

\begin{tabular}{|c|c|c|c|c|c|}
\hline Level & Name & $\begin{array}{c}\text { Date of } \\
\text { establishment }\end{array}$ & Site & $\begin{array}{c}\text { First } \\
\text { Chairman }\end{array}$ & $\begin{array}{c}\text { First } \\
\text { secretary-general }\end{array}$ \\
\hline National & $\begin{array}{c}\text { China National Orchestral } \\
\text { Association Hulusi, Bau } \\
\text { Specialized Committee }\end{array}$ & 2005.6.22 & Beijing & $\begin{array}{l}\text { Wang } \\
\text { Tiechui }\end{array}$ & He Weiqing \\
\hline \multirow{9}{*}{ Provincial } & $\begin{array}{c}\text { Hulusi, Bau Specialized } \\
\text { Committee of Hubei Province }\end{array}$ & 2007.2.8 & Wuhan & Lu Ming & Li Hancheng \\
\hline & $\begin{array}{c}\text { Hulusi, Bau Specialized } \\
\text { Committee of Shanxi Province }\end{array}$ & 2007.11.3 & Taiyuan & & \\
\hline & $\begin{array}{c}\text { Hulusi, Bau Specialized } \\
\text { Committee of Anhui Province }\end{array}$ & 2008.5.19 & Hefei & $\begin{array}{c}\text { Zhao } \\
\text { Yinbin }\end{array}$ & Fang Hongjin \\
\hline & $\begin{array}{c}\text { Shanxi Province Orchestral } \\
\text { Association Hulusi, Bau } \\
\text { Specialized Committee } \\
\end{array}$ & 2009.4.26 & Xi'an & $\begin{array}{l}\text { Wang } \\
\text { Houcheng }\end{array}$ & Li Tongsheng \\
\hline & $\begin{array}{c}\text { Guangdong Music Society } \\
\text { Hulusi, Bau Specialized } \\
\text { Committee }\end{array}$ & 2009.3.28 & Guangzhou & $\begin{array}{l}\text { Tan } \\
\text { Yanjian }\end{array}$ & Zhu Longtao \\
\hline & $\begin{array}{c}\text { Yunnan Province Hulusi, Bau } \\
\text { Specialized Committee }\end{array}$ & 2009. 12.6 & Kunming & $\begin{array}{c}\mathrm{Li} \\
\text { Guizhong } \\
\end{array}$ & Feng Xiaoli \\
\hline & $\begin{array}{l}\text { Guangzhou Provinice Hulusi } \\
\text { Bau Specialized Committee }\end{array}$ & 2010.7.3 & Guiyang & & \\
\hline & $\begin{array}{l}\text { Jiangsu Province Hulusi Bau } \\
\text { Specialized Committee }\end{array}$ & 2013.3.19 & Nanjing & Zeng Ming & Jin Lujian \\
\hline & $\begin{array}{l}\text { Hebei Province Hulusi Bau } \\
\text { Specialized Committee }\end{array}$ & 2013. & Shijiazhuang & $\begin{array}{c}\text { Xie } \\
\text { Rongtang }\end{array}$ & Wu Ye \\
\hline \multirow{2}{*}{ City level } & $\begin{array}{l}\text { Huaihua City Hulusi, Bau } \\
\text { Specialized Committee }\end{array}$ & 2007.10.31 & Huaihua & Song Hui & He Dagui \\
\hline & $\begin{array}{l}\text { Hengyang City Hulusi, Bau } \\
\text { Specialized Committee }\end{array}$ & 2008.1.7 & Hengyang & $\begin{array}{c}\text { Bin } \\
\text { Hongyong }\end{array}$ & Zhou Huiping \\
\hline
\end{tabular}




\begin{tabular}{|c|c|c|c|c|}
\hline $\begin{array}{c}\text { Huangshi City Hulusi, Bau } \\
\text { Specialized Committee }\end{array}$ & 2009.5.2 & Huangshi & Hu Jun & Qiu Huijin \\
\hline $\begin{array}{c}\text { Daqing Ethnic Orchestra } \\
\text { Society Hulusi, Bau Specialized } \\
\text { Committee }\end{array}$ & 2009.6.19 & Daqing & $\begin{array}{l}\text { Yang } \\
\text { Qingui }\end{array}$ & \\
\hline $\begin{array}{l}\text { Linyi City Hulusi, Bau } \\
\text { Specialized Committee }\end{array}$ & 2009.8.21 & Linyi & $\begin{array}{c}\mathrm{Du} \\
\text { Guangling }\end{array}$ & \\
\hline $\begin{array}{c}\text { Yuncheng City Hulusi, Bau } \\
\text { Specialized Committee }\end{array}$ & 2010.8.25 & Yuncheng & Jin Ganye & \\
\hline $\begin{array}{l}\text { Yichang City Hulusi, Bau } \\
\text { Specialized Committee }\end{array}$ & 2010.7.7 & Yichang & $\begin{array}{l}\text { Huang } \\
\text { Dahuan }\end{array}$ & \\
\hline $\begin{array}{l}\text { Weifang City Hulusi, Bau } \\
\text { Specialized Committee }\end{array}$ & 2010.10 .14 & Weifang & $\begin{array}{l}\text { Wang } \\
\text { Yuting }\end{array}$ & \\
\hline $\begin{array}{l}\text { Xianyang City Hulusi, Bau } \\
\text { Specialized Committee }\end{array}$ & 2011.4 .9 & Xianning & Ke Yuming & \\
\hline $\begin{array}{l}\text { Jiaxing City Hulusi, Bau } \\
\text { Specialized Committee }\end{array}$ & 2011.12.22 & Jiaxing & Yan Qiduan & Zheng Qiyan \\
\hline $\begin{array}{l}\text { Yueyang City Hulusi, Bau } \\
\text { Specialized Committee }\end{array}$ & 2011.11.25 & Yueyang & & \\
\hline $\begin{array}{c}\text { Huitong County Hulusi, Bau } \\
\text { Specialized Committee }\end{array}$ & 2012.1.1 & $\begin{array}{l}\text { Huitong } \\
\text { County }\end{array}$ & & \\
\hline $\begin{array}{c}\text { Dehong Hulusi, Bau } \\
\text { Specialized Committee } \\
\end{array}$ & 2012.3.6 & Dehong & $\begin{array}{l}\text { Gong } \\
\text { Jiaming } \\
\end{array}$ & \\
\hline $\begin{array}{l}\text { Qianghuangdao City Hulusi, } \\
\text { Bau Specialized Committee }\end{array}$ & 2012.4 .9 & Qianghuangdao & $\begin{array}{c}\text { Liu } \\
\text { Yongxin } \\
\end{array}$ & \\
\hline $\begin{array}{c}\text { Zhaozhuang City Hulusi, Bau } \\
\text { Specialized Committee }\end{array}$ & 2012.8 .13 & Zhaozhuang & $\begin{array}{c}\text { Dong } \\
\text { Dingran } \\
\end{array}$ & Yang Yuren \\
\hline $\begin{array}{l}\text { Handan City Hulusi, Bau } \\
\text { Specialized Committee }\end{array}$ & 2012.8.25 & Handan & $\begin{array}{c}\text { Qin } \\
\text { Zhenhai }\end{array}$ & Yan Shuping \\
\hline $\begin{array}{l}\text { Wuxi City Hulusi, Bau } \\
\text { Specialized Committee }\end{array}$ & 2013.7.10 & Wuxi & $\begin{array}{c}\text { Zeng } \\
\text { Guiming } \\
\end{array}$ & \\
\hline $\begin{array}{l}\text { Wenzhou City Hulusi, Bau } \\
\text { Specialized Committee }\end{array}$ & 2014.1.18 & Wenzhou & Li Xinhong & $\begin{array}{c}\text { Ye Xiaosen Huang } \\
\text { Zhiqiang } \\
\end{array}$ \\
\hline $\begin{array}{l}\text { Baoji City Hulusi, Bau } \\
\text { Specialized Committee }\end{array}$ & 2014.4.13 & Baoji & Yu Wei & Yang Songsen \\
\hline $\begin{array}{c}\text { Huai'an City Hulusi, Bau } \\
\text { Specialized Committee }\end{array}$ & 2014.4.19 & Huai'an & $\begin{array}{c}\text { Meng } \\
\text { Lingxin } \\
\end{array}$ & Wu Haiping \\
\hline $\begin{array}{c}\text { Changsha City Hulusi, Bau } \\
\text { Specialized Committee }\end{array}$ & 2014.5.11 & Changsha & Xiao Yun & \\
\hline $\begin{array}{l}\text { Nanchang City Hulusi, Bau } \\
\text { Specialized Committee }\end{array}$ & 2014.5.17 & Nanchang & $\begin{array}{c}\text { Yang } \\
\text { Guoping }\end{array}$ & Han Zhonghui \\
\hline $\begin{array}{l}\text { Nantong City Hulusi, Bau } \\
\text { Specialized Committee }\end{array}$ & 2014.11.16 & Nantong & $\begin{array}{l}\text { Huang } \\
\text { Yaling }\end{array}$ & Wang Jianrong \\
\hline
\end{tabular}

The Institute was established Flute music is booming in recent years, a reflection of their affiliated local musicians association, as its secondary learn to work to make music led by Hulusi advance unorganized, in a self-generated self-destruction of the liberal arts and cultural status into an organized community arts and cultural leadership bodies. The Institute has developed fast, high-impact features. From the China Nationalities Orchestra Society Hulusi, Bau Professional Committee since (the first Hulusi, Bau professional societies) was established in June 22, 200510 or so years, Hulusi levels, Bau Institute has set up dozens of and more, this growth rate is difficult to achieve other professional societies. The Society for the specification spread Hulusi, Bau music, resulting in a greater impact. Since the establishment of these institutions, through active development of members, to carry out various exchange activities greatly boosted the spread Hulusi, Bau art. To improve the quality of the people, building a harmonious society, promote national culture, foreign cultural exchanges in various social activities, has played a positive role in promoting and facilitating. 


\section{The role of Hulusi Bau society for Hulusi music's development}

Hulusi Bau societies in municipalities and regions, carry out work through a series of activities and vigorously promote the Hulusi, Bau progress and development of music culture.

\section{Show exchange}

Performances frequent exchanges between the Society organized the Hulusi, Bau provides both music lovers exchange stage performances, but also for understanding and improve their level of play of great help, social impact and efficiency significantly.

\section{Holding lectures}

Hold high-level talks is to improve regional integrity Hulusi, Bau playing an effective means of horizontal. As invited by the country's Li Chunhua held several seminars to learn about Hulusi, in Beijing, Tianjin, Zhengzhou, Wuhan, Jingzhou, Hangzhou, Xinyang, Xuzhou, Taiyuan, Xianyang, Sanmenxia, Xiaogan, Linyi, Shenzhen, Guangzhou, Dongying, Yueyang, Nanyang, Nanjing, Yuncheng, Zhenjiang and other places to do Flute music lectures [1]. These seminars for the dissemination Flute music has a more profound impact, under the continuing impact of these lectures, learn not previously established places have set up a Hulusi, Bau learn.

\section{Holding playing contest}

In recent years, more and more competition around the play, mostly by local Hulusi, Bau learn organization hosting. More influential are the China Nationalities Orchestra Society Hulusi, Bau Beijing National Invitational Tournament sponsored by the Committee and the Professional Musicians Association Yunnan Hulusi, Bau Professional Committee of Kunming, Yunnan Hulusi, Bau National Invitational, these two events of the radiation, while some other major events have an impact in place (shown in Table 2).

Table 2. Hulusi Bau Contents in recent years

\begin{tabular}{|c|c|c|c|c|}
\hline Contest Name & Date & Site & Host & Groups \\
\hline $\begin{array}{l}\text { First Yunnan } \\
\text { Hulusi, Bau } \\
\text { Invitational }\end{array}$ & 2009.12.29 & $\begin{array}{l}\text { Yunnan Arts } \\
\text { Institute }\end{array}$ & $\begin{array}{l}\text { Yunnan Society of } \\
\text { Musicians Hulusi } \\
\text { Bau Specialized } \\
\text { Committee }\end{array}$ & $\begin{array}{c}\text { Children group, infant group, Junior A, } \\
\text { Junior B, Youth group, Middle age group, } \\
\text { the elder group }\end{array}$ \\
\hline $\begin{array}{l}\text { Second Yunnan } \\
\text { Hulusi, Bau } \\
\text { Invitational }\end{array}$ & 2011.5.20 & $\begin{array}{l}\text { Yunnan Arts } \\
\text { Institute (old } \\
\text { campus) }\end{array}$ & $\begin{array}{l}\text { Yunnan Society of } \\
\text { Musicians Hulusi } \\
\text { Bau Specialized } \\
\text { Committee }\end{array}$ & $\begin{array}{c}\text { Infant group, children group, junior group, } \\
\text { youth group, middle age group, the elder } \\
\text { group }\end{array}$ \\
\hline $\begin{array}{l}\text { Third Yunnan } \\
\text { Hulusi, Bau } \\
\text { Invitational }\end{array}$ & 2013.5.10 & $\begin{array}{l}\text { Yunnan Arts } \\
\text { Institute(Mayuan } \\
\text { old campus) }\end{array}$ & $\begin{array}{l}\text { Yunnan Society of } \\
\text { Musicians Hulusi } \\
\text { Bau Specialized } \\
\text { Committee } \\
\end{array}$ & $\begin{array}{c}\text { Infant group, children group, junior group, } \\
\text { youth group, middle age group, the elder } \\
\text { group }\end{array}$ \\
\hline $\begin{array}{l}\text { Guangdong } \\
\text { Province First } \\
\text { Hulusi, Bau } \\
\text { National } \\
\text { Invitational }\end{array}$ & 2010.8.7 & $\begin{array}{l}\text { Xinghai } \\
\text { Conservatory of } \\
\text { Music }\end{array}$ & $\begin{array}{l}\text { Guangzhou } \\
\text { Society of } \\
\text { Musicians Hulusi } \\
\text { Bau Specialized } \\
\text { Committee }\end{array}$ & $\begin{array}{c}\text { Infant group, Children's A group, } \\
\text { Children's B group, Junior's A group, } \\
\text { Junior's B group, Youth A group, Youth B } \\
\text { group, Middle age group A, Middle age } \\
\text { group B, the elder A group, the elder B } \\
\text { group }\end{array}$ \\
\hline $\begin{array}{c}\text { Guangdong } \\
\text { Province Second } \\
\text { Hulusi, Bau } \\
\text { National } \\
\text { Invitational }\end{array}$ & 2014.8.16 & $\begin{array}{c}\text { Guangdong } \\
\text { Vocational College } \\
\text { of Art }\end{array}$ & $\begin{array}{c}\text { Guangdong } \\
\text { Society of } \\
\text { Musicians Hulusi } \\
\text { Bau Specialized } \\
\text { Committee }\end{array}$ & $\begin{array}{c}\text { Infant group, Children's A group, } \\
\text { Children's B group, Junior's A group, } \\
\text { Junior's B group, Youth A group, Youth B } \\
\text { group, Middle age group A, Middle age } \\
\text { group B, the elder A group, the elder B } \\
\text { group }\end{array}$ \\
\hline
\end{tabular}




\begin{tabular}{|c|c|c|c|c|}
\hline $\begin{array}{l}\text { Beijing City } \\
\text { Hulusi, Bau } \\
\text { National } \\
\text { Invitational }\end{array}$ & 2009.6.15 & Beijing & $\begin{array}{l}\text { China Ethnic } \\
\text { Music Orchestra } \\
\text { Society Hulusi } \\
\text { Bau Specialized } \\
\text { Committee }\end{array}$ & $\begin{array}{l}\text { Children's solo group 1, Children's solo } \\
\text { group 3, Junior's solo group 1, Junior's } \\
\text { solo group 2, Junior's solo group 3, } \\
\text { Youth's solo group 1, Youth's solo group } \\
\text { 2, Middle age's solo group, the elder's } \\
\text { solo, collective children group, collective } \\
\text { youth, collective middle and elder group }\end{array}$ \\
\hline $\begin{array}{l}\text { Beijing City } \\
\text { Hulusi, Bau } \\
\text { National } \\
\text { Invitational }\end{array}$ & 2012.6 .5 & Beijing & $\begin{array}{l}\text { China Ethnic } \\
\text { Music Orchestra } \\
\text { Society Hulusi } \\
\text { Bau Specialized } \\
\text { Committee }\end{array}$ & $\begin{array}{l}\text { Children's solo group 1, Children's solo } \\
\text { group 3, Junior's solo group 1, Junior's } \\
\text { solo group 2, Junior's solo group 3, } \\
\text { Youth's solo group 1, Youth's solo group } \\
\text { 2, Middle age's solo group, the elder's } \\
\text { solo, collective children group, collective } \\
\text { youth, collective middle and elder group }\end{array}$ \\
\hline $\begin{array}{l}\text { Zunyi City 1ST } \\
\text { Hulusi, Bau } \\
\text { National } \\
\text { Invitational }\end{array}$ & 2014.3.1 & $\begin{array}{l}\text { Zunyi Normal } \\
\text { College }\end{array}$ & $\begin{array}{l}\text { Zunyi Ethnic } \\
\text { Music Orchestra } \\
\text { Society Hulusi } \\
\text { Bau Specialized } \\
\text { Committee }\end{array}$ & $\begin{array}{c}\text { Category group: Infant group, Children } \\
\text { group, Junior group, Youth group, Middle } \\
\text { age group, the Elder group, Combination } \\
\text { group } \\
\text { Professional group: Teenage Hulusi } \\
\text { professional group, Tenage Bau } \\
\text { professional group, Adult Hulusi } \\
\text { professional group, Adult Bau } \\
\text { professional group }\end{array}$ \\
\hline $\begin{array}{l}\text { Baoji City } \\
\text { Hulusi, Bau } \\
\text { National } \\
\text { Invitational }\end{array}$ & 2014.5.1 & $\begin{array}{l}\text { Yihe Grand Hotel in } \\
\text { Baoji }\end{array}$ & $\begin{array}{l}\text { Baoji City } \\
\text { Musicians } \\
\text { Association } \\
\text { Hulusi, Bau } \\
\text { Specialized } \\
\text { Committee }\end{array}$ & $\begin{array}{c}\text { Infant group, Children group, Junior } \\
\text { group, Youth group, Middle age group, } \\
\text { the Elder group }\end{array}$ \\
\hline $\begin{array}{l}\text { Kunming 1st } \\
\text { Hulusi Art } \\
\text { Festival } \\
\text { Invitational }\end{array}$ & 2014.6.1 & Kunming, Yunnan & $\begin{array}{c}\text { Kunming Society } \\
\text { of Musicians } \\
\text { Hulusi Bau } \\
\text { Specialized } \\
\text { Committee }\end{array}$ & $\begin{array}{c}\text { Children group, Junior group, Youth } \\
\text { group, Middle age group, the Elder group, } \\
\text { Combination group }\end{array}$ \\
\hline
\end{tabular}

\section{Holding original works contest}

In order to better promote the popularity and prosperity of the arts gourd Siba Wu, Chinese Ethnological Society Orchestra Hulusi, Bau Society of Professional Committee of Nationalities Orchestra in the United Anhui Hefei, Anhui Province in October 20095 and October 5, 2013 held twice Hulusi, Bau original contest (shown in Table 3).

Table 3. Two sessions Hulusi, Bau original works contest in Hefei City

\begin{tabular}{|c|c|c|c|c|}
\hline Contest name & $\begin{array}{c}\text { Holding } \\
\text { date }\end{array}$ & Site & Host & $\begin{array}{c}\text { 1st prize and } \\
\text { author }\end{array}$ \\
\hline $\begin{array}{l}\text { "Binhu Cup" 1st } \\
\text { Hulusi Bau } \\
\text { Original Works } \\
\text { Contest }\end{array}$ & 2009.10.5 & $\begin{array}{l}\text { Hefei } \\
\text { Yangtze } \\
\text { River } \\
\text { Theater }\end{array}$ & $\begin{array}{l}\text { Anhui Provincial Department of Culture; } \\
\text { China Nationalities Orchestra Society } \\
\text { Hulusi, Bau Professional Committee; } \\
\text { Ethnological Society Orchestra Anhui } \\
\text { Province; Hefei Municipal Propaganda } \\
\text { Department of the CPC; }\end{array}$ & $\begin{array}{l}\text { 1. Desert Springs } \\
\text { Wu Qilin } \\
\text { 2. Bonfire Night } \\
\text { Fever Zhang } \\
\text { Xiaodong } \\
\text { 3. Zhang Yimeng } \\
\text { and early spring, } \\
\text { Zhang Rundong } \\
\text { 4. Binhu night in } \\
\text { spring Zheng Jiayu }\end{array}$ \\
\hline $\begin{array}{l}\text { Second National } \\
\text { Hulusi Bau } \\
\text { Original Works } \\
\text { Contest }\end{array}$ & 2013.10 .5 & $\begin{array}{l}\text { Big theatre } \\
\text { in hefei }\end{array}$ & $\begin{array}{l}\text { China Nationalities Orchestra Society } \\
\text { Hulusi, Bau Professional Committee; Anhui } \\
\text { National Orchestra Society; }\end{array}$ & $\begin{array}{l}\text { 1. Dream return to } \\
\text { Tianshan Sun } \\
\text { Kaicheng } \\
\text { 2. Huangmei } \\
\text { hometown for new } \\
\text { year's fun, Zhao } \\
\text { Yinbin }\end{array}$ \\
\hline
\end{tabular}




$$
\begin{aligned}
& \text { 3. Dancer girl } \\
& \text { Zhang Xiao } \\
& \text { 4. Dream Yelang } \\
& \text { Wang Dengjia, } \\
& \text { Zhang Xiao }
\end{aligned}
$$

The event aims to promote traditional Chinese culture, showing the latest achievements in the past five years, the National gourd Siba Wu playing creative work, to further promote the popularity and prosperity of the country gourd Siba Wu artistic career. Selected activities in response to the country has been widely gourd Siba Wu arts, but also received strong support from the community and the China Nationalities Orchestra Society, and other units. This activity on the development of Hulusi, Bau music has had a profound impact. Hulusi produced a number of outstanding works and also produced a number of outstanding Hulusi musicians such as Weishi Jian, Zhang Xiao, Wu Qilin, Sun Kaicheng, these works and these emerging Hulusi Hulusi music composer is music to today the performance of prosperity and witness.

Hulusi country, Bau Society have also carried out a number of other activities, such as organizing teaching training, theory seminars, Forum, etc. These activities undoubtedly also reflects the Hulusi, Bau Hulusi Music Society in the development process an important role.

\section{Significance of Hulusi Bau society for Hulusi music's development}

\section{Cultural transmission and development of various regions}

Hulusi, Bau Institute can establish provinces Flute music lovers to organize, enhance mutual understanding and exchanges, healthy and beneficial activities to better make positive efforts and contributions to the development and prosperity of the provincial culture and art, while the provinces Hulusi Art next level.

\section{Carry forward Chinese culture of excellence}

Hulusi, Bau music not only permeated with thousands of years of cultural connotation, but also has a distinctive ethnic characteristics and strong ethnic style. Whether it is sound, or the external structure have a high aesthetic value. Also because of its unique cultural characteristics of ethnic sounds and folk music to become the brightest spot in the garden of renowned throughout the world. For example: Dehong in Yunnan Hulusi, Bau Association inaugural meeting, Dehong CPC Standing Committee, propaganda minister Li Yanlan speech at the inaugural meeting, she noted, "Hulusi is Dehong most representative of the many arts and culture of folk musical instruments, Hulusi, Bau Society, is an important carrier and platform Hulusi Hulusi cultural and artistic development and prosperity and development of cultural industries, but also an important force to promote national culture and building a strong state useful supplement, the state commission, the state government guide the establishment of gourd Siba Wu Society, and as an important way to accelerate the pace of development of cultural industries, promote cultural development and prosperity, is conscientiously implement the party's seventh session of the Sixth Plenary Session, the provincial Ninth Party Congress and state Sixth Party Congress spirit of specific initiatives; heritage protection is Hulusi arts and culture, promote the need for excellent national culture and arts; Hulusi is to promote the sustained and rapid development of cultural industry needs. "[2].

Since Hulusi levels, Bau Society was founded, through active development of members, greatly promote the spread of Hulusi, Bau artistic development, it is also in response to the establishment of the country Hulusi, Bau lovers of learning requirements, better promote the gourd silk, Bau musical development. It not only enhance the Hulusi, Bau position in China and internationally, but also for the revitalization of the Chinese nation and carry forward the traditional culture, heritage, development of the motherland minority instrumental foundation, the vast Hulusi, Bau spirit musicians and lovers homes for Flute music culture heritage and development has played a pivotal role. 


\section{Acknowledgement}

This article is school level research project of Hubei Institute of Engineering, Project Name: Cultural background analysis of contemporary Hulusi music development, No.: r2014027.

\section{References}

[1] Liu Hongfei. Li Chunhua's Hulusi's music achievement, Ethnic music, 2013(3).

[2] Li Weichang. Dehong State Society of Hulusi Bau was established, Gong Jiaming was elected as chairman, Hometown of Peafowl. 